\title{
COVID-19 variants: The undetectable and invisible
}

\author{
Jared Robinson, Alexandra Leclézio, Indrajit Banerjee \\ Sir Seewoosagur Ramgoolam Medical College, Belle Rive, Mauritius
}

\section{LETTER TO EDITOR}

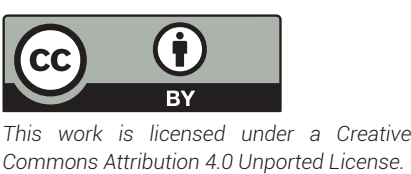

Commons Attribution 4.0 Unported License.
The novelty and high transmissibility of the SARS-CoV-2 virus has seen the world face multiple waves of surges with millions of infections and deaths. The difficulties in both the diagnosis and subsequent containment of the virus has been a continuous worldwide battle. The most vital tool that has been at the disposal of worldwide governments has been the isolation of positive cases and thus has been the mainstay modus operandi of minimizing the transmission and spread of the virus. What would the implications be if we could no longer accurately diagnose the infection? A new variant of the SARS-CoV-2 virus have been discovered in France and is proving elusive to the gold standard testing. ${ }^{\text {? }}$

COVID-19 specific tests: Currently the three mainstay diagnostic tests are nucleic acid amplification tests, viral sequencing and serology. The gold standard group of tests being nucleic acid amplification tests, namely PCR. The Principle of these tests is to locate and identify genetic similarities in the Ribonucleic acid of the SARS-CoV-2 virus namely the genes encoding for $\mathrm{N}, \mathrm{E}$ and $\mathrm{S}$ proteins. The amplification tests include nucleic acid sequencing and real-time reverse- transcription polymerase chain reaction $(r R T-P C R)^{2,3}$

The French variant discovered in Brittany: A new variant of the SARS-CoV-2 virus has been discovered in a cluster of eight cases in a hospital in Lannion in Brittany, France. The peculiarity however in these cases is that they were admitted with the symptoms of COVID-19, yet did not test positive whence their specimens were sent for the gold standard PCR testing. This new variant has the ability to evade the gold standard PCR test and thus makes the variant virtually "invisible" to the mainstay means of testing used globally. It is reported that these 8 cases are part of a cluster of 79 patients. This new strain is currently believed to not have an enhanced virulence or transmission capability as seen with other variants. 4,5

Conclusion: The implication of an undetectable strain is disastrous and thus calls for the development of a more rapid, accurate and reliable test which is specifically targeted towards the mutations. If this undetectable variant follows the trend of the other mutations with enhanced virulence and transmission capabilities the outcome could be cataclysmic. The variant would fundamentally cripple the current global protocol and mainstay modus operandi of minimizing the transmission via isolation and contact tracing of positive cases

\section{REFERENCES}

1.Pullano G, Di Domenico L, Sabbatini CE, et al. Underdetection of cases of COVID-19 in France threatens epidemic control. Nature. 2021 Feb;590(7844):134-9.

https://doi.org/10.1038/s41586-020-03095-6

2.Mohabeer P, Banerjee I, Kashyap A, Shukla A, Robinson J, Ramdhan ND. SARS-CoV-2-an update in virology: A Narrative Review. Journal of Biomedical Sciences. 2020 Dec 31;7(2):77-87. https://doi.org/10.3126/jbs.v7i2.34007

3.Bastos ML, Tavaziva G, Abidi SK, Campbell JR, Haraoui LP, Johnston JC, Lan Z, Law S, MacLean E, Trajman A, Menzies D, Benedetti A, Ahmad Khan F. Diagnostic accuracy of serological tests for covid-19: systematic review and metaanalysis. BMJ. 2020 Jul 1;370:m2516.

https://doi:10.1136/bmj.m2516

4.France investigates new coronavirus variant detected in Brittany. HEALTHCARE \& PHARMACEUTICALS. Reuters. [online 2021] [cited 2021 March 28] Available from: URL: https://www.reuters.com/article/us-health-coronavirusfrance-variant/new-coronavirus-variant-found-in-frenchregion-of-brittany-french-government-idUSKBN2B80GQ

5.Fourcade M. France Finds Covid-19 Variant That Evades Gold-Standard Tests. Prognosis. Bloomberg. [online 2021] [cited 2021 March 28] Available from: URL: https://www. bloomberg.com/news/articles/2021-03-16/france-findsvariant-in-brittany-that-evades-standard-tests

*Corresponding Author

Dr. Indrajit Banerjee

Associate Professor

Department of Pharmacology

Sir Seewoosagur Ramgoolam Medical College, Belle Rive, Mauritius 